4

\begin{tabular}{|c|c|}
\hline ARTICLE INFORMATION & Fill in information in each box below \\
\hline Article Type & Short Communications \\
\hline Article Title & $\begin{array}{l}\text { Macroscopic, histological, and microbiological characterization of contact } \\
\text { lesions at the tibiotarsal region of broilers }\end{array}$ \\
\hline Running Title (within 10 words) & Characterization of contact lesions in the tibiotarsal region of broilers \\
\hline Author & $\begin{array}{l}\text { Ricardo Cavani }{ }^{*} \text {, Marcela da Silva Rubio }{ }^{1} \text {, Khauston Augusto Pereira Alves }{ }^{2} \text {, } \\
\text { Lucas José Luduverio Pizauro }{ }^{1} \text {, Marita Vedovelli Cardozo }{ }^{3} \text {, Paulo Lourenço } \\
\text { Silva }^{4} \text {, Iran José Oliveira Silva }{ }^{5}, \text { Fernando Antônio Avila }^{1}\end{array}$ \\
\hline Affiliation & $\begin{array}{l}1 \text { São Paulo State University (UNESP), School of Agricultural and Veterinary } \\
\text { Sciences, Jaboticabal, São Paulo, Brazil } \\
2 \text { Cesumar University, Maringa, Paraná, Brazil } \\
{ }^{3} \text { Minas Gerais State University, Passos, Minas Gerais, Brazil } \\
{ }^{4} \text { Uberlandia Federal University, Uberlandia, Brazil } \\
{ }^{5} \text { São Paulo University, Piracicaba, São Paulo, Brazil }\end{array}$ \\
\hline $\begin{array}{l}\text { Special remarks - if authors have additional } \\
\text { information to inform the editorial office }\end{array}$ & \\
\hline $\begin{array}{l}\text { ORCID (All authors must have ORCID) } \\
\text { https://orcid.org }\end{array}$ & Not a \\
\hline $\begin{array}{l}\text { Conflicts of interest } \\
\text { List any present or potential conflict s of } \\
\text { interest for all authors. } \\
\text { (This field may be published.) }\end{array}$ & are no potential conflict of interest. \\
\hline $\begin{array}{l}\text { Acknowledgements } \\
\text { State funding sources (grants, funding } \\
\text { sources, equipment, and supplies). Include } \\
\text { name and number of grant if available. } \\
\text { (This field may be published.) }\end{array}$ & Not applicable \\
\hline $\begin{array}{l}\text { Author contributions } \\
\text { (This field may be published.) }\end{array}$ & $\begin{array}{l}\text { Conceptualization: Cavani R. } \\
\text { Data curation: Cavani R., Rubio, MS, Alves KAP, Pizauro LJL } \\
\text { Formal analysis: Cavani R., Rubio, MS, Alves KAP, Pizauro LJL. } \\
\text { Methodology: Cavani R. } \\
\text { Investigation: Cavani R., Rubio, MS, Alves KAP, Pizauro LJL. } \\
\text { Writing - original draft: Cavani R., Rubio, MS, Alves KAP, Pizauro LJL. } \\
\text { Writing - review \& editing: Cavani R., Rubio, MS, Alves KAP, Pizauro LJL., } \\
\text { Cardozo MV, Silva PL, Silva IJO, Avila FA }\end{array}$ \\
\hline $\begin{array}{l}\text { Ethics approval (IRB/IACUC) } \\
\text { (This field may be published.) }\end{array}$ & $\begin{array}{l}\text { The experiment was approved by the Ethics Committee on the Use of Animals } \\
\text { (CEUA) under protocol no. 1183/21, located at São Paulo State University } \\
\text { (UNESP), School of Agricultural and Veterinary Sciences, Jaboticabal, São } \\
\text { Paulo, Brazil. }\end{array}$ \\
\hline
\end{tabular}

5

6 CORRESPONDING AUTHOR CONTACT INFORMATION

\begin{tabular}{|l|l|}
\hline $\begin{array}{l}\text { For the corresponding author } \\
\text { (responsible for correspondence, } \\
\text { proofreading, and reprints) }\end{array}$ & Fill in information in each box below \\
\hline First name, middle initial, last name & Ricardo Cavani \\
\hline $\begin{array}{l}\text { Email address - this is where your proofs } \\
\text { will be sent }\end{array}$ & $\begin{array}{l}\text { Corresponding author for manuscript ricardocavani@hotmail.com } \\
\text { Please, for proofs and reviews copy to ma.rubio192@gmail.com }\end{array}$ \\
\hline Secondary Email address & $\begin{array}{l}\text { Corresponding author for manuscript ricardocavani@hotmail.com } \\
\text { Please, for proofs and reviews copy to ma.rubio192@gmail.com }\end{array}$ \\
\hline Postal address & $\begin{array}{l}\text { Department of Veterinary Pathology, São Paulo State University (UNESP), } \\
\text { School of Agricultural and Veterinary Sciences, Via de Acesso Prof. Paulo } \\
\text { Donato Castellane s/n, Jaboticabal, São Paulo 14884-900, Brazil }\end{array}$ \\
\hline Cell phone number & Not applicable \\
\hline
\end{tabular}




\section{Macroscopic, histological and microbiological characterization of contact lesions in the tibiotarsal region of broilers}

ABSTRACT - Brazil is considered as a great broiler feet exporter, especially for the Chinese trade. Contact lesions at the tibiotarsal region are responsible for economic losses and there is no model for its classification, thereby this study presents a fast and practical grade system to be used in the poultry industry and proposes these lesion characterizations into three different grades. For this, correlation was made between macroscopic, histological findings and microbiological quantification (Escherichia coli, Staphylococcus spp., Streptococcus spp. and sulphite-reducing clostridia) from contact lesions in the tibiotarsal region of 112 broiler carcasses, divided in four groups ( $\mathrm{n}=28)$, accordingly to the lesion's intensity. It was possible to observe that grade 1 and 2 lesions, because of been in an early stage and per not present significant histopathological alteration such as few or absent ulceration, they obtained similar microbiological quantification ( $>0.05$ ) when compared with the control group. In grade 3 lesion group, it was observed bacterial cocci grume and ulceration at the articular region and significant higher microbiological count $(\mathrm{p}<0.05)$ for E. coli and Staphylococcus spp. In conclusion, the visual standard proposed in this work, correlated and confirmed by the histopathologic, and microbiologic characterization, allow to precise and fast ascertainment of the contact lesion grade in the tibiotarsal regions of broiler carcasses. Moreover, it should be highlighted that grades 1 and 2 alterations are not caused by an inflammatory process caused by pathogenic agents and should not be considered a public health risk therefore.

Keywords: Hock burn, dermatitis, slaughterhouse, carcass condemnation, inspection line.

Running Title: Characterization of contact lesions in the tibiotarsal region of broilers 


\section{Introduction}

Brazil is an important broiler feet exporter to the Asian trade, especially China and Hong Kong, which consider this product as a delicacy in their gastronomy and as collagen supplement for the cosmetic and medicine industry (ApexBrasil, 2018; Munasinghe et al., 2014). Moreover, it is considered in many countries, as well as in Brazil, as the third cut of chicken with the highest economic value (Chen et al., 2016).

Among the main factors for the condemnation of broiler feet are the contact lesions and keratosis. The contact lesions in the tibiotarsal region, also known as hock burn, contact dermatitis and dermatitis are characterized by the presence of blackish or brownish coloration on the skin of the chickens' tibiotarsal region (Bessei, 2006). Besides the economic losses due to discards, it also impairs the broilers performance and violates the technical recommendation of animal welfare in poultry production, because it results in pain for the bird, evidenced by the slowly locomotion or even reluctance to move (Louton et al., 2020).

It is known that the weight is a risk factor that can be associated with the occurrence of lesions on broiler legs (Louton et al., 2018) and that it will simultaneously acts alongside the bad litter quality and the presence of infectious agents (Thøfner et al., 2019). The litter of the poultry house is used to provide a better life quality for the birds since it contributes to the thermal comfort and avoid direct contact with the floor or tread, preventing the formation of calluses in the animal's leg and breast. Besides the litter absorbs and incorporates the waste, such as excrete, desquamation, feathers and food and water residues that fall from the feeders and drinking fountains (Avila et al., 2008). According to Olsen et al. (2018), the high humidity and high ammonia concentrations originated from the accumulated faecal matter result in ammonia gas liberation that causes chemical burns and weakening of the dermis. In addition, the humidity makes the external dermis softens, facilitating the entry and proliferation of microorganisms. 

histopathological validation for this assessment scheme was just recently described (Louton et al., 2020). Besides, until now, only the correspondence between the macroscopic aspects of the lesions and their histopathological characteristic was demonstrated with no correlation between their microbiological content. Nevertheless, since no standard visual method was developed to compare this kind of lesion, this study aimed to present a fast and practical visual grade to be used in the industry and validated with the histological findings and microbiological quantification in the tibiotarsal region in broiler carcasses.

\section{Materials and Methods}

\section{Ethics statement}

The experiment was approved by the Ethics Committee on the Use of Animals (CEUA) under protocol no. 1183/21 from São Paulo State University (UNESP), School of Agricultural and Veterinary Sciences, Jaboticabal, São Paulo, Brazil.

\section{Experimental facilities}

This study was conducted in a commercial slaughterhouse located in the Sao Paulo state, Brazil, with a slaughter capacity of 120.000 birds/day. The birds came from 14 producers of the Northern regions of the Sao Paulo state. The bird batches were of the Cobb and Ross linages, with a mean of 42 days of age and $2.8 \mathrm{~kg}$ of weight at the slaughter.

\section{Experimental design}

For this study, 112 broiler carcasses were obtained at the post-mortem inspection line (pre-inspection) with or without visual characteristics of contact lesion at the tibiotarsal region. Then, carcasses were removed from the inspection line and with the aid of a disinfect knife in 
alcohol $70 \%$, the leg was removed by disarticulating the tibiofemoral region, followed by the disarticulation and removal of the metatarsophalangeal region. Each sample was constituted by a single joint, having collected 28 articulations for each evaluated grade $(n=28)$, which were packed either in sterile bag under refrigeration or flasks containing $10 \%$ formaldehyde and, thus, sent to the laboratory for analysis.

\section{Visual classification}

For evaluation and visual classification of the tibiotarsal joint, to attribute a macroscopic score of the lesions, was carried out over a period of six months and the lesions were divided into four different groups: a control group (CG) and grades 1 (G1), 2 (G2) and 3 (G3). It was used a total of $942(\mathrm{CG}=234, \mathrm{G} 1=236, \mathrm{G} 2=235$ and $\mathrm{G} 3=237)$ pictures of tibiotarsal region observed in the post-mortem inspection line to perform macroscopic classification. The grading methods was based on the principals described by Welfare-Quality® (2009) and Louton et al. (2020), utilizing fewer lesion grades (three instead of four) that were created based on characteristics such as intensity and color of the contact lesion in the tibiotarsal region and the presence or absence of scarification.

\section{Histopathological evaluation}

The samples harvested for histopathological examination were placed in flasks containing $10 \%$ formalin and sent to the "Centro de Diagnóstico de Sanidade Animal" (CEDISA, Concordia, SC, Brazil). The histological sections were stained with hematoxylin and eosin for evaluation of the epidermis, dermis and hypodermis (subcutaneous) of the tibiotarsal region. 


\section{Microbiological evaluation}

The microbiological analysis were performed at the "Laudo Laboratório Avícola Uberlândia Ltda" (LAUDO, Uberlandia, MG, Brazil). From the refrigerated samples for microbiological count, sterile swabs were scraped on a $5 \mathrm{~cm}^{2}$ area of the articular surface. After sampling, the swabs were placed in tubes containing $5 \mathrm{~mL}$ of $1 \%$ Buffered Peptone Water solution (Neogen Corporation, Lansing, USA). After sampling, E. coli, Staphylococcus spp. and sulphite-reducing clostridia were quantified using $3 \mathrm{M}^{\mathrm{TM}}$ Petrifilm ${ }^{\mathrm{TM}}$ Plates (3M do Brazil, Sumaré, Brazil), and Streptococcus spp. used Blood agar with 5\% Sheep Blood plates (Laborclin, Pinhais, PR, Brazil) as described by Chadfield et al., (2004).

\section{Statistical analysis}

Microbiological data were subjected to statistical analysis using the R-Project for Statistical Computing (Wilson and Norden, 2015) and Python for Data Analysis software (Tobergte and Curtis, 2013). Microbiological counts were logarithmic transformed and after not passing the normality test (Shapiro-Wilk), the results were evaluated with a non-parametric Kruskal-Wallis test and statistical significance of the groups were evaluated by the paired sample Wilcoxon test and considered statistically significant when the $p$-value was lower than $5 \%(\mathrm{p}<0.05)$

\section{Results and discussion}

Considering the principals described by Welfare-Quality® (2009) and Louton et al. (2020) and the characteristics about the intensity and coloration of the contact lesions at the tibiotarsal region, the lesions were allocated in four different grades: the control group (GC) the articulation without visual alteration; Grade 1 (G1), refers to the joint with mild scarification and pink or reddish color (erythema); Grade 2 (G2), refers to the joint with moderate 
scarification, crust formation and brownish coloration; Grade 3(G3) refers to the articulation with scarification of severe intensity, presence of crust, ulceration and/or brownish and/or purplish and/or blackish coloration (Figure 1).

The classification of contact injuries prove to be widely diversified, both nationally and internationally. Some of them focus on the size of the lesion (Arnould et al., 2009; Pagazaurtundua and Warriss, 2006a; Pagazaurtundua and Warriss, 2006b; Welfare-Quality®, 2009) whereas others combine size and depth (Allain et al., 2009; Ekstrand et al., 1998; Kaukonen et al., 2016; Kjaer et al., 2006) in different categories. Therefore, the differences of this varieties of assessment systems may not well elucidated and has been a challenge for both scientific point of view and the quality of surveillance systems (Michel et al., 2012; Riber et al., 2020). Thus, it was suggested herein a model for these gross lesions classifications to further be used in accordance with histological and microbiological analysis.

In the histopathological characterization was described that in the CG articulation was not observed noteworthy lesions. In the G1 and G2 groups, it was observed histological alterations only in the superficial regions of the skin, whereas in G1, there were a moderate proliferation of subcutaneous connective tissue, with no signs of inflammation. Moreover, in G2 was observed a moderate proliferation of connective tissue, with a mild ulceration focus of the skin and formation of a keratin crust and degenerated inflammatory cells, considered as a morphological diagnose of mild focal necrotic dermatitis.

In G3 were observed ulceration in the epidermis and dermis, with the presence of crusts of necrotic tissue, keratin, degenerated inflammatory cells and clumps of bacteria in the form of cocci. In the subcutaneous (hypoderm), it was observed proliferation of connective tissue, with deposition of fibrin lump and, mild presence of hemorrhage and inflammatory infiltrate, with the heterophile predominance. These characteristics are considered a morphological find of focally extensive necrotic dermatitis. The inflammation severity of the lesions increased with 
the crescent macroscopic score, in which the visually more severe and deeper lesions, also presented more accentuated histological findings, especially considering the presence of inflammatory cell and remnants of inflammation (proliferation of connective tissue and presence of fibrin) (Martins et al., 2016).

The microbiological quantification results, described in Table 1, corroborates with the histopathological characterization, in which no inflammatory reaction of bacterial origin was observed in samples from CG and G1 and G2 and bacterial cocci clumps in G3 samples. In the evaluated samples was not evidenced the presence of sulfite-reducing clostridia, and the counts of E. coli, Staphylococcus spp. and Streptococcus spp. of the control group and grade 1 and 2 were within the acceptance threshold required by Brazil and importing trades such as the United States, China, Eurasian Economic Union, Saudi Arabia, South Africa, and others. (AVA, 2000; Brasil, 2017; Brasil 2019; China, 2014; EC, 2005; GSO, 2014; NB, 2017). By statistical tests, when comparing the results of the CG with the other grades, it was not observed significant differences $(\mathrm{P}>0.05)$, except in $\mathrm{G} 3$, which differed from the control group and other grades.

Although there is an extensive repertoire of information about the predisposing factors for the occurrence of contact injuries in tibiotarsal joints of broiler, especially those related to bedding quality, nutrition, and management, little is known about the microbiological factors associated with these conditions and that could be considered inadequate (Olsen et al. 2018). Chadfield et al. (2004) suggested that E. coli, Staphylococcus spp. and Streptococcus spp. are opportunistic bacteria that can prevenient from the bird's own organism, which would explain the similarity $(\mathrm{P}>0.05)$ in bacterial counts observed for $\mathrm{G} 1$ and $\mathrm{G} 2$ when compared to the control group.

In the case of mild lesions (G1), in which the skin was preserved intact and in the moderate lesions (G2), where only the superficial skin layer was compromised, there was no microbial invasion into the tissues, which Allain et al. (2009) characterize them as "chemical 
burns" that are the results of the high amount of humidity of the litter and/or high concentration of ammonia in the fecal matter. In contrast, the accentuated skin deterioration process allow for the opportunistic microorganism to invade the subcutaneous tissue (Nagase et al. 2002). That fact was observed in the present study in lesions of G3, in which there was the presence of ulceration and increased bacterial counts, as described by Martins et al. (2016) who observed the presence of areas of necrosis and the presence of inflammatory infiltrate in severe contact lesions.

Thus, the classification of lesions into three scores of hock dermatitis proposed in this work by means of macroscopic, histopathological and microbiological findings provided a simple, practical and scientific-based way for its use both in the poultry industry, as well as in poultry farms in Brazil. Such grouping allows for easier identification, in addition to enabling better characterization of the evolution of changes in the animals, a fact evidenced both by histopathological findings (presence of connective tissue, inflammatory infiltrate, ulceration and the formation of keratin crust) and by microbiological findings (increasing microorganisms quantification).

\section{Conclusion}

The visual standard proposed in this work, which was correlated and confirmed by the histopathological and microbiological characterization, allows a faster and precise ascertainment of the degrees of contact lesions in tibiotarsal joints of broilers. Furthermore, it is noteworthy that grades 1 and 2 alterations are not due to an inflammatory process caused by pathogens and, therefore, do not represent a public health concern.

\section{References}

Allain V, Mirabito L, Arnould C, Colas M, Le Bouquin S, Lupo C, Michel V. 2009. Skin lesions 
in broiler chickens measured at the slaughterhouse: relationships between lesions and between their prevalence and rearing factors. Br Poult Sci 50:407-417.

ApexBrasil. 2018. Trade and investment opportunities in china food and beverage. Available from: https://www.cebc.org.br/2019/03/28/oportunidades-de-comercio-e-investimentona-china-alimentos-e-bebidas/. Accessed at Aug 11. 2021.

Arnould C, Butterworth A, Knierim U. 2009. Standardisation of clinical scoring in poultry. In: Assessment of animal welfare measures for layers and broilers. Forkman B, Keeling L, (ed). p. 7-30. Welfare Quality ${ }^{\circledR}$ Series 9, Langford, BC, ENG.

AVA. 2000. Agri-Food and Veterinary Authority. Circular/Directive n. 2000/1 Microbiological specifications for imported meat, Singapore, SG.

Avila VS, Oliveira U, Figueiredo EAP, Costa CAF, Abreu VMN, Rosa PS. 2008. Evaluation of alternative materials to replace wood shavings as aviary bedding. Rev Bras Zootec 37:273-277.

Bessei W. 2006. Welfare of broilers: A review. Worlds Poult Sci J 62:455-466.

Brasil. 2017. Memorandum n 36/2017/DIPOA/MAPA/SDA/MAPA. Ministry of Agriculture, Livestock and Supply. Brasilia, DF, BR.

Brasil. 2019. OFFICIAL NOTICE No 33/2019/CGCOA/DIPOA/SDA/MAPA. Ministry of Agriculture, Livestock and Supply. Brasilia, DF, BR.

Chadfield MS, Christensen JP, Christensen H, Bisgaard M. 2004. Characterization of streptococci and enterococci associated with septicaemia in broiler parents with a high prevalence of endocarditis. Avian Pathol 33:610-617.

Chen J, Tellez G, Escobar J. 2016. Identification of biomarkers for footpad dermatitis development and wound healing. Front Cell Infect Microbiol 6:1-11.

China. 2014. Nationalf ood standard fresh and frozen poultry products. GBT 16869-2005. GB National Standards of People's Republic of China, Beijing, CN. 
EC. 2005. Microbiological criteria for foodstuffs. Commision Regulation (EC) No 2073/2005. Official Journal of the European Union, Brussels, BE.

Ekstrand C, Carpenter TE, Andersson I, Algers B. 1998. Prevalence and control of foot-pad dermatitis in broilers in Sweden. Br Poult Sci 39:318-324.

GSO. 2014. Microbiological criteria for foodstuffs. GSO /FDS 1016 / 2014. Standardization organization for G.C.C (GSO). Riyadh, KSA.

Kaukonen E, Norring M, Valros A. 2016. Effect of litter quality on foot pad dermatitis, hock burns and breast blisters in broiler breeders during the production period. Avian Pathol 45:667-673.

Kjaer JB, Su G, Nielsen BL, Sørensen P. 2006. Foot pad dermatitis and hock burn in broiler chickens and degree of inheritance. Poult Sci 85:1342-1348.

Louton H, Bergmann S, Reese S, Erhard M, Bachmeier J, Rösler B, Rauch, E. 2018. Animaland management-based welfare indicators for a conventional broiler strain in 2 barn types (Louisiana barn and closed barn). Poult Sci 97:2754-2767.

Louton H, Piller A, Bergmann S, Erhard M, Stracke J, Spindler B, et al. 2020. Histologically validated scoring system for the assessment of hock burn in broilers. Avian Pathol $49: 230-242$.

Martins BB, Martins MRFB, Mendes AA, Fernandes BCS, Aguiar EF. 2016. Footpad dermatitis in broilers: Differences between strains and gender. Rev Bras Cienc Avic 18:461-466.

Michel V, Prampart E, Mirabito L, Allain V, Arnould C, Huonnic D, et al. 2012 Histologicallyvalidated footpad dermatitis scoring system for use in chicken processing plants. Br Poult Sci 53:275-281.

Munasinghe KA, Schwarz JG, Nyame AK. Chicken Collagen from Law Market Value ByProducts as an Alternate Source. J Food Process. 2014:1-6. 
Nagase N, Sasaki A, Yamashita K, Shimizu A, Wakita Y, Kitai S, Kawano, J. 2002. Isolation and species distribution of staphylococci from animal and human skin. J Vet Med Sci $64: 245-250$.

NB. 2017. Carnes y derivados - Poultry meat - Microbiological requirements. NB:310013. La Paz, BO.

Olsen RH, Christensen H, Kabell S, Bisgaard M. 2018. Characterization of prevalent bacterial pathogens associated with pododermatitis in table egg layers. Avian Pathol 47:281-285.

Pagazaurtundua A, Warriss PD. 2006a. Measurements of footpad dermatitis in broiler chickens at processing plants. Vet Rec 158:679-682.

Pagazaurtundua A, Warriss PD. 2006b. Levels of foot pad dermatitis in broiler chickens reared in 5 different systems. Br Poult Sci 47:529-532.

Riber AB, Rangstrup-Christensen L, Hansen MS, Hinrichsen LK, Herskin MS. 2020. Characterisation of footpad lesions in organic and conventional broilers. Animal 14:119128.

Thøfner ICN, Poulsen LL, Bisgaard M, Christensen H, Olsen RH, Christensen JP. 2019. Correlation between footpad lesions and systemic bacterial infections in broiler breeders. Vet Res 50:1-5.

Tobergte DR, Curtis S. 2013. Python for Data Analaysis. O’Reilly., Sebastopol, UA

Welfare-Quality®. 2009. Welfare Quality ® Assessment protocol for poultry. Welfare Quality Consortium, Lelystad, NL. p 111.

Wilson A, Norden N. 2015. The R Project for statistical computing. The R Foundation., Vienna, AT. 
Table 1. Microbiological quantification of E. coli, Staphylococcus spp. and Streptococcus spp. in contact lesions in the tibiotarsal joint of broiler chickens.

\begin{tabular}{lccc}
\hline \multirow{2}{*}{ Grade } & \multicolumn{3}{c}{ Microrganism $(\mathbf{C F U} / \mathrm{ml})$} \\
\cline { 2 - 4 } & $\boldsymbol{E}$. coli & Staphylococcus spp. & Streptococcus spp. \\
\hline Control & $4,70 \times 10^{1 \mathrm{a}}$ & $2,73 \times 10^{2 \mathrm{a}}$ & $1,80 \times 10^{3 \mathrm{a}}$ \\
Grade 1 & $9,30 \times 10^{1 \mathrm{a}}$ & $4,40 \times 10^{2 \mathrm{a}}$ & $1,16 \times 10^{3 \mathrm{a}}$ \\
Grade 2 & $1,50 \times 10^{2 \mathrm{a}}$ & $8,10 \times 10^{2 \mathrm{a}}$ & $1,11 \times 10^{3 \mathrm{a}}$ \\
Grade 3 & $4,50 \times 10^{4 \mathrm{~b}}$ & $2,60 \times 10^{5 \mathrm{~b}}$ & $4,80 \times 10^{4 \mathrm{a}}$ \\
\hline
\end{tabular}

Means followed by different letters in the columns, differ from each other by the Kruskal-Wallis and the 


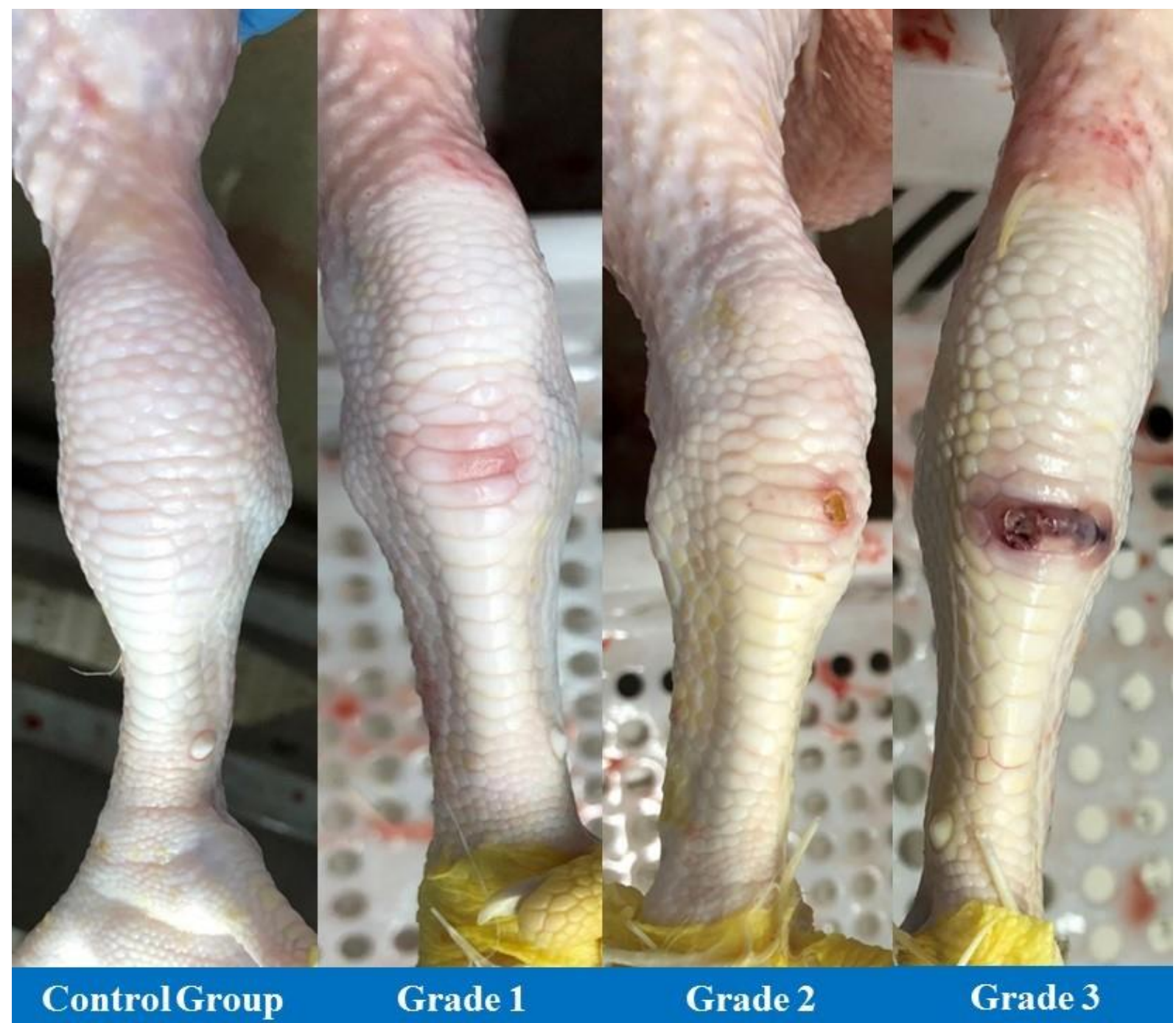

Figure 1. Macroscopic classification of the contact lesion grades at the tibiotarsal region of broilers. Control group: No visible alteration; Grade 1: Mild scarification and pinkish or reddish (erythema) coloration; Grade 2: Moderate scarification, crust formation and brownish coloration; Grade 3: severe scarification, presence of crust, ulceration and brownish and/or purplish and/or blackish coloration. 